\title{
Teachers' Proffesional in Integrating Material of Semangko Faulth and Megatrush Mentawai in Learning Geography at Senior High School in Indonesia (Case Study at Senior High School in Agam Regency)
}

\author{
Muhammad Ilham \\ Student of Gography Education Master Program, \\ Faculty of Social Science, Universitas Negeri Padang, INDONESIA \\ Email: ilham.mikoshu@gmail.com
}

\begin{abstract}
The purpose of this research was to describe and analysis of teachers' professional in integrating material of semangko faulth and megatrush Mentawai in learning geography. This research was a descriptive qualitative research. The data collection techniques used were observation, interviews, and documentation. The informants in this study were teachers of the geography of SMA Negeri 1 Ampek Angkek Kabupaten Agam as much as 2 teachers. Data analysis used reduction, data presentation, and conclusion. The results showed that: professional level of teachers in the integration materials of Faulth Semangko and Megatrush Mentawai in geography learning was $71.56 \%$ with the two categories, the ability to plan the organization in the integration of the material Semangko Faulth and Megatrush Mentawai. Teachers were not maximized although this integration was submitted by adjusting the conditions and situations that occur in the environment. The master plan of Teaching and Learning Activity Management that with reference to the achievement of competence and select and prepare appropriate learning procedure (steps teach) in accordance with the curriculum guide device. Teachers have to maximize its ability to plan classroom management and observes the conditions and situation of student learning in the opening stage, the core activity, closing activities, and assessment. Teachers also plan the use of media and learning resources were better at each of meetings. Teachers plan an assessment of student achievement in geography on human and environmental materials as a result of the dynamics of the lithosphere.
\end{abstract}

Keywords: Professional of Teachers Competence, Materials of Geography

\section{Introduction}

Nowaday, we are faced with various problems that need to be considered in the term of education quality. Teachers are the dominant factor in improving quality of the learning process. They need more serious attention because they are "development agents", which plays an important role in the education of the nation. Therefore, various political activities have and will continue the efforts to improve: career, quality, respect, and well-being. One important policy is promoting promotion of teachers with a performance at work. The work, according to the field of activity: (1) education, (2) learning process, (3) professional development and (4) supporting the learning process.

Decree of the Minister of State Administrative Reform of the State Republic Indonesia No. 84/1993 on the functional position of teachers and the credit note and joint decree of the Minister of Education and Culture and head of the BAKN number 0433 / P / 1993 number 25 of 1993 in principle aim to favor a career of professional rank and professionalism. These policies require teachers to undertake activities in their area 
of competence, and only for those who manage to do well-given credit score activities. In addition, credit score has been used as one of the requirements of career improvement.

In education, successful teachers of their role are largely in its ability to carry out the different roles that are specific to the situation of teaching and learning. Slameto (2013), describes the teacher has the task of encouraging, guiding and providing learning facilities for students to achieve learning goals. According to Nurfuadi (2012), learning is a business that intentionally involves and uses the professional knowledge that teachers have to achieve the program's objectives. Teachers not only a be profession, but must be competent qualified to perform their duties according to the professionalism of teachers needed directors. The competence of teachers is regulated in Permendiknas No 16 of 2007 for the professional competence of geography teachers must have a fundamental competency that is: (1) mastery of the concept, and knowledge model that support subjects ; (2) master the level of competence and basic competence of the subjects ; (3) developing creative learning materials; (4) developing professionalism in a sustainable manner by taking thoughtful action; (5) use information and communication technologies to develop.

This fundamental competence can be seen in the teachers' Geography of SMA N Agam in their learning. Nursid Sumaatdmaja (2001) suggests that learning geography is a study that studies the scattered areas of the earth and forms certain geographical environments that show the regional system and some ecosystem. Suharyono (2006) explains that the purpose of learning geography in schools is threefold: knowledge, attitudes, and skills. Learning objectives that can be seen in the object the dynamics of the lithosphere human relations and environmental impacts in X class. Dynamics of the lithosphere that occur are on Semangko Faulth and Megatrush Mentawai which can cause various disasters in West Sumatra and the surrounding area, particularly in the area Semangko Faulth and near Megatrush Mentawai for addressing the phenomenon and to apply the geography of contextual learning. As a geography teacher must provide knowledge of the phenomenon to learners. In order for the subsequent learning of geography to translate into real benefits, especially in everyday life, and that knowledge is the first step towards adaptation to the environment. Therefore, the development of educational material by integrating geography Megatrush Mentawai and Semangko Faulth in Geography learning, are able to increase the professionalism of geography teachers in achieving the learning objectives.

\section{Method}

This research was a descriptive study using qualitative research methods as shown Moleong (2010) is the research that led to the analysis procedure which uses no quantification of statistical analysis procedures or other means. This research was conducted in the SMA N Agam regency, West Sumatra province in August-September 2017. According to Moleong (2010), Informants are people in the research that are used for information about the situation and the background of the research. This researchers using purposive sampling techniques. According to Mardalis (2010) directed sampling has a purpose or on purpose, how to use the sample (informants) can represent the characteristics of the population that has been identified was selected geography teacher at SMAN 1 IV angkek Agam. This research uses data collection techniques by observation, interview, and documentation. The data of research in the form of primary and secondary data, and then analyzed with the phase of data reduction, data verification, data interpretation and concluded. The next step was technical fact check the validity of the data with steps; extend participation to due diligence during research, triangulation phase and peer review through data discussion. 


\section{Results and Discussion}

Teacher professional in Integration material of Semangko Faulth and Megatrush Mentawai in geography learning at senior high school level

Professional level of teachers in this research was considered in terms of integration and equipment Semangko Faulth and Megatrush Mentawai in geography learning the secondary level in Agam, can be presented in the following table:

Table 1. Teacher professional in integration material of Semangko Faulth and Megatrush Mentawai in geography learning at senior high school level

\begin{tabular}{|l|l|l|l|}
\hline No & Indicators & $\begin{array}{l}\text { Score } \\
(\%)\end{array}$ & Criteria \\
\hline 1 & Organize the integration of materials & 61.63 & Not good \\
\hline 2 & KBM Management & 75.31 & Good \\
\hline 3 & Classroom management & 72.40 & Good \\
\hline 4 & Use of Media and Learning Resources & 75.66 & Good \\
\hline 5 & Assessment of Student Outcomes & 72.81 & Good \\
\hline Sub-variable Criterion & 71.56 & Good \\
\hline
\end{tabular}

Source: Primary Research Data, 2017

Semangko Faulth and Megatrush Mentawai in Geography learning was an implementation of contextual learning. This material was directly related to environmental conditions of West Sumatra which straddles Semangko Faulth and Megatrush Mentawai in Indonesia. Oiseaux, P. (2003) explained that Indonesia has a very active tectonic zone due to three large plates of the world and nine small slab meet in Indonesia and establish pathways slab assembly complex. Yeats, R (1997) explains that the existence of interactions between these plates places the territory of Indonesia as an area very vulnerable to earthquakes. Earthquakes on the island of Sumatra represent the geodynamic implications of active deformation around the Sunda and Java strait. Madlazim (2010) describes the occurrence of an earthquake near the limit of the meeting between the oceanic slab that pierces the continental plate and is classified as a subduction zone. The Sumatra subduction zone extends from the Sunda Strait in the north to the Andaman Sea Located in a very active tectonic zone resulting from numerous tectonic activities, the subduction zone of the island of Sumatra extends from North Sumatra to South Sumatra SFZ (Sumatra Fault Zone).

Mardrinovella (2011) explains that the boundaries of convergent slab on two rigid plates enter the Eurasian slab and the Indo-Australia create dis-slip terrain models shaped happens along the Sumatra subduction zone (megathrust). Hendra (2017) describes Megathrust as a seismic or superficial rupture term (more than $60 \mathrm{~km}$ ) from the boundary between the slab (the Indian Ocean slab) and the slab above it. The term megathrust is popular after the publication of the results of doctoral research Danny Hilman and Professor Kerry Sieh as his mentor at the California Institute of Technology. His work appeared in the Journal of Geophysical Research on NeoTectonics of Sumatra Fault in 2000 and the paleo geodesy of the Sumatra subduction zone in 2004 became the benchmark of many quake experts in Sumatra.

In the western part of Indonesia, Madlazim (2011) explains precisely the southern region of the island of Sumatra known to have a Sumatran fault zone called the Semangko Fault which divides the island of Sumatra into two parts. Putri, et al (2016) explain her research activity Semangko fault because of the earthquake in Aceh and Sianok Segment have the same type of earthquake that is, without a tremor preliminary in the land. The calculations show the appropriate method for estimating the end aftershocks Aceh and Sianok segment is a method of Mogi 2. The result of Sianok segmented provides more of actual data rather than segments of Aceh. Over the magnitude major earthquake then more the expiration of aftershocks that occurred. Salim and Santosa (2014) describe the results of research has shown that the 
processing of seismic data caused by the fault Mentawai fault reversal has a fault pattern and the dip-slip fault pattern.

Media Viva (2017) says the Meteorological Agency of Climatology and Geophysics has noted, since 1900 to 2014, at least 16 times a devastating earthquake around Megathrust Mentawai, West Sumatra. Four of them caused a large tsunami. The impact of the earthquake took place September 30, 2009, the most devastating, which has a strength of 7.9 on the Richter scale. The earthquake killed 1,100 people, 2,181 people were injured and more than 2,650 buildings were damaged, and communications and power lines disconnected by landslides. Based on the description and the facts Mentawai Megatrush sure Semangko Faulth should strongly support learners geography of contextual learning.

Judging by the ability to plan the integration of materials Semangko Faulth organizing equipment and Megatrush Mentawai still not good Geography topics who were submitted by adjusting the conditions and situations that occur in the environment around the child, as well as local and national coverage. Environmental issues are already covered in the certain equipment related materials accordance tectonism geography program. Regarding the preparation of the study of the integration of materials to be submitted, teachers manuals studying subjects that will be submitted namely textbooks and the previous module in accordance with tectonism Resources which would be submitted to the learners. Regarding the preparation of the integration of Semangko Faulth and Megatrush Mentawai, only prepared materials that are consistent with the environmental conditions of each school. It causes by the teachers familiar with the integration before Semangko Faulth and Megatrush Mentawai even in seminars regarding physical geography materials primarily. In fact, there is no director of application integration specifically Semangko Faulth and Megatrush Mentawai.

According to the opinion of A. Tabarani and Rusyan Wijaya (1992), that the competencies that must be mastered first, teacher is mastery of the field of study, while the ability of teachers to plan the integration of materials Semangko Faulth and Megatrush Mentawai apertural lithosphere at the stage of the lowest cognitive taxonomy is at this stage only the knowledge. This can happen because of using resources and Semangko Faulth and Megatrush Mentawai considered another aspect that is less fundamental/essential and the proportion is slightly under the related topics. Teachers are more focused on providing all materials where the main topic of integration Semangko Faulth and Megatrush Mentawai just stuck. Yet, according to Wijaya and A. Tabrani Rusyan (1992), teachers must know and understand the types of materials in the field of study firstly. Equipment of Semangko Faulth and Megatrush Mentawai an example of a description of the geography questions directly to the environment.

The Ability Teaching Learning Management Plan is seen on the teacher's ability to formulate conditions competence is good because it has formulated the basic competencies and indicators that have sorted out the real nature of things toward more abstract things. Thus, the competency can describe the knowledge, skills, and attitudes that result from the learning outcomes. This was consistent with that expressed by Soemarsono (in Arikunto 2005: 133), that jurisdiction is an object that describes the knowledge, skills, competencies, and attitudes that should belong to students because of learning outcomes expressed in terms of behavior (behavior) which can be observed and measured. With the formulation of the competence of teachers have a direction and limits of the teaching of a material that reduces the likelihood of an interval (interval) or near the other (overlap) of the material. Regarding teaching methods, teachers are always well-planning methods because of the method used is quite varied ranging from conferences, questions and answers, discussion, experience, missions, and observation (at school and at home). Thus, the teacher has recognized and used various learning methods and is very important when the teacher has had the experience of teaching more than 25 years. 
Related to that, it is in accordance with that presented by Wijaya and A. Tabrani Rusyan (1992), that knowing and being able to use teaching method is the basic ability of teachers who are most important in achieving success in school. Mastery teachers to the teaching methods used will encourage the achievement of the effectiveness of the learning that takes place. Content integration process and Megatrush Mentawai Semangko Faulth continued teacher with four (4) step, program planning, preparation of integration, the integration of the implementation, and provide an evaluation activity. The ability to formulate these steps is also closely related to the method chosen by the teacher in their lesson. In this sub-indicator is known the measures taken by the teacher was very good, because he described the sequence of the learning process according to proposed by Wijaya and A. Tabrani Rusyan (1992), that for the success of the teaching, the teacher must understand all the steps must be taken that possible.

Based on the ability classroom management planning conclude that the teacher is well known. As known that classroom management is a process to control the behavior of students in promoting the atmosphere in class. In addition, the enabling class atmosphere to be able to provide results of the study among university students and non-academic. Through the state of the well-managed classroom, the motivation that the energy of students learning very powerful students goes grow and function effectively. This is in accordance with the opinion of DePorter, Bobbi. Mark Reardon and Sarah Singer-Nourie (2003), that bench/seat development plays a very important role in supporting the learning process.

The seating arrangement will affect the smooth adjustment of teaching and learning process. Structuring classrooms and student lounge allow students to move freely not to upset or interfere with each other between a student with other students while they study. By arranging the seats allow teachers face to face once more able to control student behavior. From this research, teachers have a variety of manners plan the layout of the dining chairs and students. The postman age which over 40 years most teachers can certainly affect the level of maturity of thinking and acting to direct students in the most favorable learning.

The ability to allocate time consisting of four (4) steps, from the time of initiation, core activities, closing activities, and evaluation, is essential to the allocation of management of the delivery of material that has been prepared. Attempts to cultivate student activity can be seen in the management of learning activities by teachers against students in how to create working groups according to ability so that students can help each other to understand the material that delivered. Moreover, for answer the curiosity of students in the integration of information resources Semangko Faulth and Megatrush Mentawai, teachers try to adapt the answers and the questions of students to discuss. In harmony with what is expressed by Wijaya and A. Tabrani Rusyan (1992), the democratic attitude of the teacher allows built a good teacher-student relationship so that students always happy and full of passion and vigor in its opinion learning.

The results showed that the ability to plan the use of media and learning resources are classified as good, it can see that the media also has been provided for teachers to use more than 1 (one) of the media and learning resources adapted to documentary resources Semangko Faulth and Megatrush Mentawai to carry. In a variant of the use of media resources and learning that are used as images/pictures of posters, cards, VCD, and radio. In addition to the use environment such as school gardens and libraries have lots planned in integration Semangko Faulth and Megatrush Mentawai.

Variations in the use of media and learning resources are suggested by Sunarko (2004), that no media is used for all purposes, media selection must be adapted to the physical conditions of the media. environment and the use of learning multimedia types of educational materials) will very beneficial and facilitate the learning process of students and stimulate the passionate spirit of the students. The media and learning resources used are relatively easy to circumvent, so it seems that contextual elements can be raised. This is corroborated by Sunarko (2004) that the media and learning resources that can show you a concrete example reduce verbal (blind comprehension). 
It is known that planning for the evaluation of learning outcomes of students is good for teachers to know and measure students have been mastered the material lithosphere in integrated Semangko Faulth and Megatrush Mentawai or not. With results assessing the ability of the student learning are very well, he will be able to determine which students are eligible to continue to learn because he has mastered the material and who have been mastered the material. In addition to the ability of good planning, evaluation can be seen that the material Semangko Faulth and Megatrush Mentawai was appropriate or not.

The ability of teacher planning in the evaluation of student performance for educational seen in students' learning outcomes already good. It can be related with Budisulistyo (2003), through good judgment then the teacher will know what is being taught is appropriate for students or not. Teacher planning would change very positive feedback in terms of selection of the type of evaluation used in determining the extent of the control of students of matter and Semangko Faulth material Megatrush Mentawai delivered. The variations in the type of assessment that teachers are similar to what was presented Budisulistyo (2003) to obtain the balance of the three domains in the results of the study required attention in the design of assessment tools. This was manifested in the planning of teachers who used a variety of assessment types.

\section{Conclusion}

Based on the results of research regarding professional teachers in the integration of Semangko Faulth and Megatrush Mentawai in the teaching of geography at senior high school in Indonesia, we can conclude that: in general, teachers professional level of in the integration of materials and Megatrush Mentawai Faulth Semangko in learning geography was $71.56 \%$ as a good category. The ability to plan the integration of the material organization Semangko Faulth and Megatrush Mentawai, the teacher was is not maximized, but integration is on the topics of geography was submitted by adjusting the conditions and situations that occur in the environment. Plan director teaching and learning management activities to achieving skills and select and prepare the appropriate learning procedure (steps teach) according to the program guide device. Teachers have maximized their ability to plan classroom management, and observation of student learning conditions and situations at the opening, core, closing and evaluation stages. Teachers also plan to use better media and learning resources at each meeting point. Teachers evaluation plan of learning for success in geography students of human material and the environment due to the dynamics of the lithosphere.

\section{References}

Arikunto, Suharsimi. (2005). Fundamentals of the evaluation of education. Revised edition. The fifth ipression. Jakarta: the literacy of the earth

Bird, P., (2003), An updated numerical model of plate boundaries: Geochemistry, Geophysics, Geosystems, v. 4, no. 3, 1027, doi: 10.1029 / 2001GC000252.

Budisulistyo, Hasan. (2003). "Development of CBC Evaluation". Paper presented in Seminar on Teaching and Learning for Teachers of the IPS - Semarang Geography, Semarang, Department of Geography FIS UNNES in cooperation with Diknas Kota Semarang, from 23 to October 24

Deport, Bobbi., Mark Reardon and Sarah Singer-Nourie. (2003). Quantum Learning: Practicing quantum learning in classrooms. Translated by Ary Nilandari. 11th impression. Edition I. Bandung: Kaifa

Hendra, Y. 2017). Megathrust mentawai free citizen energy panic. Media Indonesia, http://mediaindonesia.com/news/read/120429/megathrust-mentawai-lepaskan-energi-warga-panik (October 4th Consulted, 2017)

Joint Order of the Minister of Education and Culture and Head of BAKN No. 0433 / P / 1993 No. 25 of 1993 on Implementation Guidelines for Functional Teachers and Credit Notes. 
Decree of the Minister of State for Administrative Reform of the State Number: 84/199, concerning the Functional Position of the Teacher and the Credit Rating.

Madlazim. (2011). CMT estimate, fault fields and duration of the earthquake in Sumatra, as well as possible implementation for the tsunami early warning system. Dissertation Department of Physics FMIPA ITS Surabaya.

Mardrinovella, I., Widiyantoro, S., Irwan, M., (2011). Relocation of the Padang earthquake hypocenter September 30, 2009 using the double difference method. JTM Vol.XVIII No. 1

Hhistory Peek earthquake megathrust in Mentawai . (2 September 2017). Media Viva. http://www.viva.co.id/berita/nasional/952545-mengintip-sejarah-gempa-di-megathrust-mentawai (accessed October 4, 2017)

Nurfuadi. (2012). The professional teachers. Stain Press. Purwokerto

Nursa Sumaatmadja. (2001). Methodology of teaching geography. Script of the earth. Jakarta

Regulations of the Minister of National Education of the Republic of Indonesia Number 16 Year 2007 on academic qualifications and proficiency standards

Salim. Riski, Bagus Jaya S. (2014). Analysis of fault field patterns in the subduction zone of the southern region of Sumatra following an earthquake in 2011-2014. JOURNAL OF TECHNICAL POMITS Vol. 3, No. 2, (2014)

Slameto. (2013). Learning and influencing factors. Rineka Cipta. Jakarta

Suharyono. (2006). Anthology of geography and thinking about the environment in education and teaching. Semarang: Presses UNNES

Sunarko. (2004). "Media Use in Contextual Learning (CTL)". Paper presented at SP4 Activity Seminar, FIS-UNES Geography Department, December 4

Wijaya, Cece and A. Tabrani Rusyan. (Ed.) (1992). Master basic skills in teaching and learning. Second impression. Bandung: PT Remaja Rosdakarya

Yeats R, Sieh, K, and Allen, C., (1997). The geology of earthquakes, 568 pp., Oxford Univ., Press, New York 